\author{
A. GHOLIZADEH \\ Research Institute for Fundamental Sciences (RIFS), University of Tabriz, Iran \\ E-mail: aghz_bioch@yahoo.co.in
}

\title{
MALTOSE-BINDING PROTEIN SWITCHES PROGRAMMED CELL DEATH IN NICOTIANA GLUTINOSA LEAF CELLS
}

\begin{abstract}
Maltose-binding protein (MBP) is a part of the complex regulatory and transport maltose system of Escherichia coli that is responsible for the uptake and efficient catabolism of maltodextrins through the transmembrane signaling at the expense of ATP. In the present work, this bacterial periplasmic protein was identified as a cell death inducer in Nicotiana glutinosa plant. Upon exogenous application at the concentrations more than $50 \mu \mathrm{g} / \mathrm{ml}$, purified MBP protein induced wilting and localized cell death on the leaves of test plant. DNA fragmentation assay and antioxidant enzymes activity test showed that the induced cell death might be programmed. It was predicted that maltose-binding protein signals programmed cell death $(P C D)$ upstream of reactive oxygen species (ROS) and DNA fragmentation processes in the test plant leaves. However, it needs to be clarified that how MBP switches and signals PCD in plant tissues.
\end{abstract}

Key words: cell death, E. coli, maltose-binding protein $(M B P)$, programmed cell death $(P C D)$.

Introduction. Programmed cell death (PCD) is one of the fundamental aspects of organism life. It is tightly regulated process and so its initiation depends on active plant metabolism [1]. In plants, PCD occurs during development such as senescence, somatic embryogenesis, tracheid formation, and interactions with the environmental cues including abiotic and biotic factors [2]. The molecular events and the signals that trigger it have not been fully understood and its understanding is still under processing. Several positive regulators of programmed cell death have been identified in plants. A particularly well characterized form of PCD is the Hypersensitive Response (HR) which is frequently associated with the resistance to pathogen attack in plants. It is a rapid localized cell death process, which occurs at the site of initial pathogen infection and leads to the formation of a dry lesion that functionally suppresses the pathogen growth. The earliest signaling molecules of $\mathrm{HR}$ is the initial recognition event between a pathogen encoded avirulence (avr) gene product as an elicitor and a plant resistance $(R)$ gene product which is predicted to encode receptors for pathogen-derived elicitors [3, 4]. It is speculated

(C) A. GHOLIZADEH, 2014 that the $R$ gene may act at the beginning of signaling pathways of HR-cell death program. It has been reported that the products of $R$ genes contain a nucleotide-binding domain termed as AP-ATPase (apoptosis ATPase) domain [5]. Arabidopsis $R$ genes have been cloned that confer specific recognition of viral, bacterial, and oomycete pathogens [3]. However, the sequence events that process HR phenomenon following avr/ $\mathrm{R}$ interaction have been poorly understood. Protein kinases and ankyrin domaincontaining proteins have been reported to act as downstream targets of the $R$ genes and regulate the activity of a number of transcription factors such as; basic-leucine zipper domain transcription factor or myb containing transcription factor [6].

The role of phytohormones as positive regulators of programmed cell death has been shown. Nitric acid synthesizing enzymes such as $\mathrm{P}$ protein of glycine decarboxylase complex (GDC) and nitric oxide synthase, the product of Atnos 1 gene are known as positive regulators of PCD in plants [7]. The enzyme benzoic acid 2-hydroxylase (BA2H) which involved in the biosynthesis of salicylic acid is active during the programmed cell death in plants [8].

ROS (reactive oxygen species) is well known as the early event in the activation of PCD in plants that is usually followed by the regulated expression of antioxidative enzymes such as catalase and peroxidases [9].

The roles of specific nucleases which target DNA

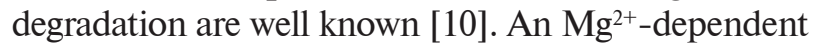
nuclease was identified in the intermembrane space of the mitochondria that recapitulates chromatin condensation and DNA fragmentation [11]. Certain proteases such as cysteine proteinases have been well characterized as PCD regulatory factors in plants [12].

Alteration of ionic homeostasis in the cytosol is among the earliest documented responses to PCD. Expression of the bacterial proton channel, bacteriopsin (bo) in tobacco results in perturbation of $\mathrm{pH}$ homeostasis and HR response [10]. Arabidopsis $d n d 1$ gene encodes a cyclic nucleotide-gated channel (CNGC) family which act as calcium channel 
regulates HR phenomenon positively [13]. hlm 1 gene encodes transporter of $\mathrm{K}^{+}$and $\mathrm{Na}^{+}$channel that induces HR [14].

Intracellular signals that are derived from lipid metabolism are also being recognized as regulators of PCD. Arabidopsis acd 11 encoding a sphingosine transfer protein causes activation of PCD and defense [15]. sfd4/fab6 which encode a plastidic $\omega 6$-desaturase have also been shown to potentiate cell death [16]. $P a d 4$ and eds 1 that encode proteins related to triacylglycerol lipases induce programmed cell death [17].

The maltose transport complex of Escherichia coli, a member of the ATP-binding cassette superfamily, mediates the high affinity uptake of maltose at the expense of ATP. The membrane-associated transporter consists of two transmembrane subunits, MalF and MalG, and two copies of the cytoplasmic ATP-binding cassette subunit, MalK. Maltose-binding protein (MBP) is a soluble periplasmic protein that delivers maltose to the $\mathrm{MalFGK}_{2}$ transporter and stimulates hydrolysis by the transporter [18, 19]. Nowadays, maltose-binding proteins are utilized as one of the best fusion tags to produce soluble recombinant proteins by $E$. coli system. Most of the expressed proteins are usually able to fold into their biologically active conformations when fused to MBP [20-22]. The MBP-fused proteins are often used for the basic investigations including their morpho-molecular interactions with the eukaryotic cells/tissues and several biological assays without the cleavage of their fusion parts [23, 24]. Therefore, it is essential to understood the likely interactive responses of eukaryotic cells with MBP.

Keeping these in view, we aimed to study the possible morpho-molecular responses of a plant tissue when it is exogenously interacted with the purified MBP alone. Considering the bacterial origin of MBP, the inducible cell death response was predicted in such an interaction. Interestingly, we found that MBP switches programmed cell death in $N$. glutinosa leaves at the concentration of about $50 \mu \mathrm{g} / \mathrm{ml}$.

In tobacco plants the new PCD inducers such as ultraviolet B overexposure [25] and dihydrosphingosine [26] have been reported, recently. We hope the present results may also open a new gate towards the studies with regard to the MBP-induced cell death in a plant cell and its signaling pathways in the future.

Materials and methods. Plant material and bacterial strain. Nicotiana glutinosa (a wild species of tobacco) was used as test plant for cell death related experiments. The plants were grown under the conditions with relative humidity of about $65 \%$, temperature $30 / 20{ }^{\circ} \mathrm{C}$ (day/night), and $16 / 8 \mathrm{~h}$ photoperiod at about $150 \mu \mathrm{mol} \mathrm{m} \mathrm{m}^{-2} \mathrm{~s}^{-1}$ light intensity. $E$. coli strain TB1 was used for the expression of MBP protein as described by manufacturer (pMALc2X protein fusion and purification system kit; Cat. No. E8000S; NEW ENGLAND, Bio lab).

Expression of maltose binding protein. MBP gene containing vector «pMALc2X $E$. coli expression vector» (provided in pMALc2X protein fusion and purification system kit; Cat. No. E8000S; NEW ENGLAND, Bio lab) was used as MBP source. The transformed $E$. coli strain TB1 cells were grown in bacterial rich broth media containing glucose and ampicillin under inducible condition with isopropyl-1-thio- $\beta$-D-galactoside (IPTG with a final concentration of $0.3 \mathrm{mM}$ ) at $37^{\circ} \mathrm{C}$. When $\mathrm{OD}_{600}$ of the culture reached $0.5, E$. coli cells were harvested and disrupted by sonication as described by manufacturer. Total soluble protein was extracted from bacterial lysate in extraction buffer containing 20 mM Tris-Cl pH 7.4, 200 mM NaCl, 1 mM EDTA, $1 \mathrm{mM}$ sodium azide, and $10 \mathrm{mM} \beta$-mercaptoethanol. Total protein fractions were subjected to SDS-polyacrylamide gel electrophoresis (SDS-PAGE) analysis on $10 \%$ running gel [27].

Purification of maltose-binding protein. $\mathrm{MBP}$ was purified from the crude extract of induced bacterial culture by maltose-affinity column chromatography according to the kit protocol (pMALc2X protein fusion and purification system kit; Cat. No. E8000S; NEW ENGLAND, Bio lab). It was carried out in a $2.5 \times 10 \mathrm{~cm}$ column packed with amylose resin that is specific for MBP. Maltose-binding protein was eluted out of the column with the column buffer including protein extraction buffer plus $10 \mathrm{mM}$ maltose.

Western analysis. To confirm the expression of MBP, about $1 \mu \mathrm{g}$ of purified protein was separated on $10 \%$ SDS-PAGE [27] and transferred onto nitrocellulose membrane (MD-Biosciences, USA) using blotting buffer containing $0.025 \mathrm{M}$ Tris- $\mathrm{Cl}$ $\mathrm{pH} 8.3,0.192 \mathrm{M}$ glycine and $20 \%$ ethanol. After the transfer, the blot was kept in TBS-BSA buffer (0.02 M Tris-Cl, pH 7.5, 0.5 M NaCl, $1 \%$ BSA) overnight at $4{ }^{\circ} \mathrm{C}$ and then incubated for $2 \mathrm{~h}$ with specific antiserum (anti-MAL; provided by protein expression and purification kit, NEW ENGLAND, 


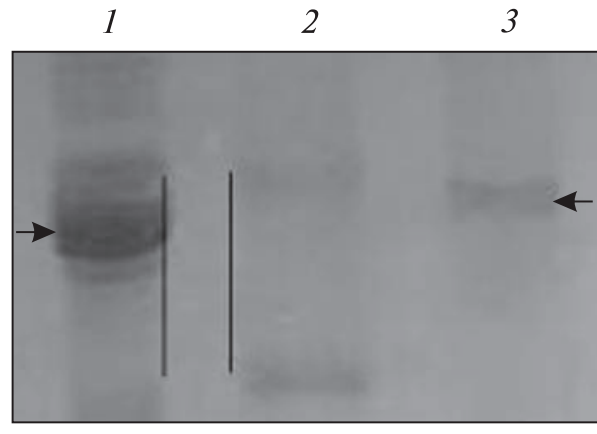

$a$
$S$

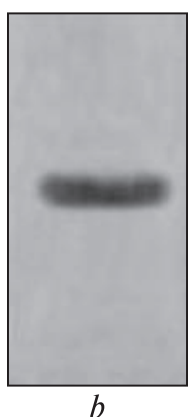

$b$
Fig. 1. SDS-PAGE and western analysis of the expressed MBP. $a$-Crude protein was extracted from the $E$. coli cells (strain TB1) carrying MBP gene containing plasmid vector and electrophpresed on $10 \%$ polyacrylamide gel; 1 - protein extract after induction with IPTG; 2 protein extract before induction with IPTG; 3 - purified MBP; $b$ - Western blotting of the purified MBP, showing a thick signal (S) corresponds to the MBP-fused protein
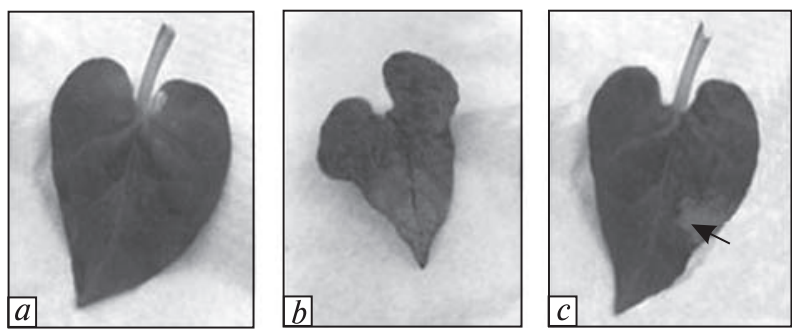

Fig. 2. Induction of death lesion. The leaves of test plant ( N. glutinosa) were treated with $50 \mu \mathrm{g} \mathrm{ml}^{-1} \mathrm{~cm}^{-2}$ of purified MBP and were observed for the morphological in a day: $a-$ a control leaf sample treated with extraction buffer, alone; $b$ - a leaf sample treated with MBP, thoroughly; $c-$ a leaf sample treated with MBP, locally

Bio labs) at $1: 500$ ratios in the same buffer at $37{ }^{\circ} \mathrm{C}$ for $1 \mathrm{~h}$. After washing with TBS-T (TBS + $+0.05 \%$ Tween 20) the membrane was incubated for $1 \mathrm{~h}$ with alkaline phosphatase conjugated goatanti rabbit antibody (GAR XAP; Promega, USA) which was diluted $1: 20,000$ in TBS-BSA buffer. After extensive washing, the signal band was visualized with a substrate solution containing nitro blue tetrazolium chloride (NBT, $0.33 \mathrm{mg} / \mathrm{ml}$ ) and 5-bromo-1-chloro-3-indolyl phosphate (BCIP, $0.165 \mathrm{mg} / \mathrm{ml}$ ) in $0.1 \mathrm{M}$ Tris- $\mathrm{Cl}$ buffer, $\mathrm{pH} 0.5$ containing $0.1 \mathrm{M} \mathrm{NaCl}$ and $5 \mathrm{mM} \mathrm{MgCl}_{2}$.

Local lesion assay. About $50-100 \mu \mathrm{g} \mathrm{ml}^{-1}$ of the purified MBP were exogenously applied on about $1 \mathrm{~cm}^{-2}$ of $N$. glutinosa leaves. Plants with the same age and vigor were used for the experiment. Fifth leaf of the six-leaf plants was considered as test material. $1 \mathrm{ml}$ of MBP-containing buffer with the defined concentrations were separately applied (rubbed with hands with gloves) on the leaf tissues. After 5 min the protein treated leaves were washed with distilled water, gently blotted dry and were evaluated for the morphological responses. Leaf samples treated with extraction buffer (containing $10 \mathrm{mM}$ maltose) were considered as controls.

DNA fragmentation assay. For DNA fragmentation test, about $100 \mathrm{mg}$ of the MBP-treated leaves were cut (at wilting and death stages, separately) and then lysed in $1 \mathrm{ml}$ of ice-cold lysis buffer containing $10 \mathrm{mM}$ Tris- $\mathrm{HCl}, 0.5 \%$ Triton $\mathrm{x}-100: \mathrm{pH} 8.0$, for $10 \mathrm{~min}$ on ice. After centrifugation of the lysate for $15 \mathrm{~min}$ at $13000 \mathrm{~g}$ and $4{ }^{\circ} \mathrm{C}$, the supernatant was extracted with phenol - chloroform - isoamyl alcohol at the rate of $25: 24: 1$ and DNA was precipitated using ethanol in the presence of $300 \mathrm{mM}$ sodium acetate at $-70{ }^{\circ} \mathrm{C}$. DNA was resuspended in $10 \mu \mathrm{L}$ of TE buffer (10 mM Tris, 1 mM EDTA, pH 8.0) and then treated with RNaseA for $1 \mathrm{~h}$ at $37^{\circ} \mathrm{C}$. DNA sample was analyzed electrophoretic on $2 \%$ agarose gel in TAE buffer (400 mM Tris, $200 \mathrm{mM}$ sodium acetate, $20 \mathrm{mM}$ EDTA pH 8.0) at $4{ }^{\circ} \mathrm{C}$ and stained with ethidium bromide. The same experiment was repeated for the control sample.

Antioxidative enzymes activity assay. Catalase. About $700 \mathrm{mg}$ of MBP-treated leaves as well as controls were separately homogenized in $2 \mathrm{ml} 0.1 \mathrm{M}$ phosphate buffer ( $\mathrm{pH} 7.0$ ) containing $1 \mu \mathrm{ml}^{-1}$ of $\beta$-mercaptoethanol and a pinch of polyvinyl pyrrolidine (PVP). The homogenates were centrifuged at $12000 \mathrm{~g}$ for $10 \mathrm{~min}$ and supernatant was used for the assay of enzyme activity. The catalase assay was done as described earlier [28]. Reaction mixture consisted of $3 \mathrm{ml}$ of $\mathrm{H}_{2} \mathrm{O}_{2}$-phosphate buffer $(0.16 \mathrm{ml}$ $\mathrm{H}_{2} \mathrm{O}_{2}$ in $100 \mathrm{ml}$ phosphate buffer $\left.0.067, \mathrm{pH} 7.0\right)$ and $0.1 \mathrm{ml}$ of extract. Blank sample consisted of $\mathrm{H}_{2} \mathrm{O}_{2}-$ free phosphate buffer plus enzyme extract. One unit of enzyme was considered as the amount of enzyme that was responsible for changing OD value of 0.01 in $1 \mathrm{~min}$. Enzyme activity was expressed as units $\mathrm{mg}^{-1}$ soluble protein.

Peroxidase. The enzyme extraction was done as the same described for catalase assay and the peroxidase activity was measured by using the previously described method [29]. The reaction mixture consisted of $3 \mathrm{ml}$ phosphate buffer $0.1 \mathrm{M} \mathrm{pH}$ 7.0, $50 \mu \mathrm{l}$ of guaicol solution $20 \mathrm{mM}, 30 \mu \mathrm{H}_{2} \mathrm{O}_{2}$ ISSN 0564-3783. Цитология и генетика. 2014. T. 48. № 2 
$(0.042 \%=12.3 \mathrm{mM})$ and $100 \mu \mathrm{l}$ of enzyme extract taken and the absorbance recorded at $436 \mathrm{~nm}$. One unit of enzyme was considered as the amount of enzyme that was responsible for changing OD value of 0.01 in $1 \mathrm{~min}$. The enzyme activity was expressed as units $\mathrm{mg}^{-1}$ soluble protein.

Phenylalanine ammonia lyase (PAL). About $700 \mathrm{mg}$ of MBP-treated leaves as well as controls were separately homogenized in $2 \mathrm{ml} 25 \mathrm{mM}$ borate buffer $\mathrm{pH} 8.8$, containing $1 \mu \mathrm{ml}^{-1}$ of $\beta$-mercaptoethanol and a pinch of PVP. The homogenate was filtered through the cheese-cloth and centrifuged at $12000 \mathrm{~g}$ for $10 \mathrm{~min}$. The supernatant was taken for the assay. The reaction mixture contained $0.5 \mathrm{ml}$ borate buffer, $0.2 \mathrm{ml}$ enzyme extract, $1.3 \mathrm{ml}$ water and $1.0 \mathrm{ml}$ substrate $(0.1 \mathrm{ml}$-phenylalanine, $\mathrm{pH} 8.7)$. It was incubated for $30 \mathrm{~min}$ at $32{ }^{\circ} \mathrm{C}$. Reaction was stopped by the addition of $0.5 \mathrm{ml} 1 \mathrm{M}$ TCA (tri-chloroacetic acid). A control sample was run simultaneously in which TCA was added before the addition of substrate. After 5 min centrifugation of the both reactions, absorbance of the supernatants was taken at $290 \mathrm{~nm}$ to measure the amount of transcinnamic acid. One unit of enzyme was considered as the amount of enzyme that was responsible for changing OD value of 1 in $1 \mathrm{~min}$. Enzyme activity was expressed as units $\mathrm{mg}^{-1}$ soluble protein.

Results. Expression of MBP in E. coli and its purification. By using expression vector system "pMALc2X» MBP was expressed in E. coli TB1 cells in the presence of IPTG. The presence of the expressed product in the crude protein extract of E. coli cells was analyzed by SDS-PAGE on $10 \%$ polyacrylamide gel (Fig. 1). As it has been shown on the photograph, MBP with a molecular weight of $42.482 \mathrm{kD}$, is highly detected on the gel (protein molecular weight marker not presented).

The MBP protein was purified from the crude extract by using single step maltose-affinity chromatography. The purity of the sample was analyzed by SDS-PAGE on $10 \%$ gel (Fig. 1, $a$ ). To confirm whether the expressed product is MBP, western blot analysis was performed using the antibody against maltose-binding protein (Fig. 1,b). The presence of a one thick band on the blot paper certificated that the expressed product is indeed MBP.

Induction of death lesions. The leaves of $N$. glutinosa were selected as test tissues to conduct a bioassay test. The leaves were treated with purified MBP protein at the concentrations of $50-100 \mu \mathrm{g} \mathrm{ml}^{-1} \mathrm{~cm}^{-2}$

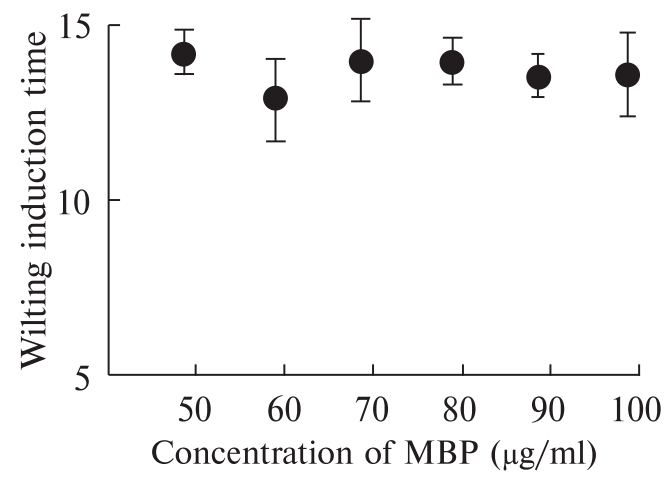

Fig. 3. Concentration-dependent local lesion assay. Lesion test was performed for different concentrations of purified MBP (between $50-100 \mu \mathrm{g} \mathrm{ml}^{-1} \mathrm{~cm}^{-2}$ ). Data are the means of three replicates $\pm \mathrm{SD}$

Fig. 4. Detection of DNA fragmentation: leaves of $N$. glutinosa plant were treated with purified MBP. The welted and the death regions of MBP treated leaves were cut and about $100 \mathrm{mg}$ of these tissues was taken for DNA extraction. Extracted DNA samples were analyzed on $2 \%$ agarose gel by using TAE buffer. The same experiment was repeated for the buffer-treated leaves as control sample: 1 intact DNA isolated from control leaves; 2 - DNA

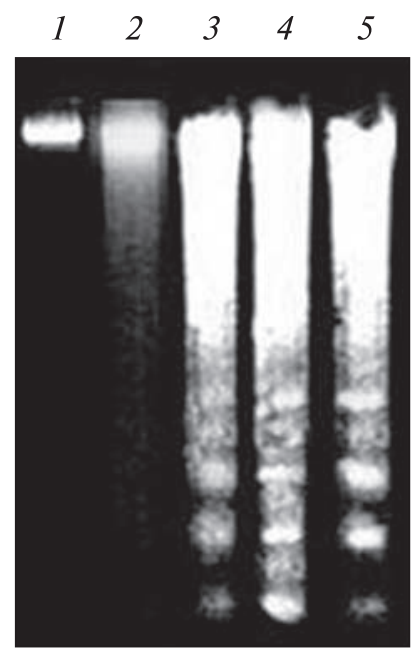
sample from welted leaves treated with purified MBP (starting fragmentation); 3, 4 and 5 represent fragmented DNA samples isolated from death areas at $30 \mathrm{~min}$ time intervals

and analyzed for its morphological interaction with the test plant. The results showed that MBP causes the wilting of the treated leaves within $15-20 \mathrm{~min}$ after treatment and then it induces brown color death lesions in the treated areas in a day (Fig. 2). No significant cell death induction is observed at the concentrations below the $10 \mu \mathrm{g} \mathrm{ml}^{-1}$ of purified MBP. In the control leaves treated with protein extraction buffer, no welting and cell death induction are observed (Fig. 2). Further experiments showed that between the protein concentrations of 50$100 \mu \mathrm{g} \mathrm{ml}^{-1}$, the induction of localized cell death apparently is not in a dose-dependent manner and in 


\section{A. Gholizadeh}
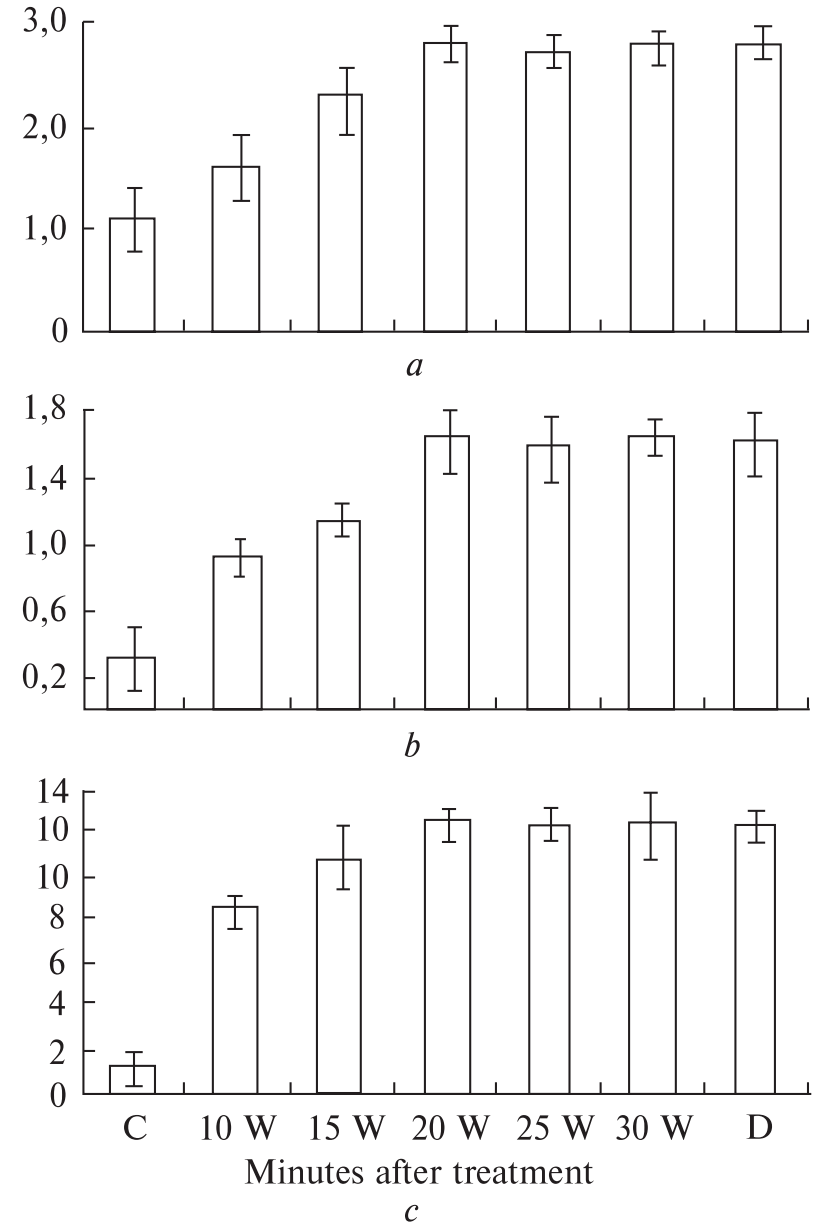

Fig. 5. Assessment of antioxidant enzyme activities: $a-$ catalase; $b$ - peroxidase; $c$ - PAL (units $\mathrm{mg}^{-1}$ protein). About $700 \mathrm{mg}$ of leaf materials taken from the MBP-treated areas were homogenized in $2 \mathrm{ml} 0.1 \mathrm{M}$ phosphate buffer $\mathrm{pH}$ 7.0 containing $1 \mu \mathrm{ml}^{-1}$ of $\beta$-mercaptoethanol and a pinch of polyvinyl pyrrolidine (PVP). The homogenates were centrifuged at $12000 \mathrm{~g}$ for $10 \mathrm{~min}$ and supernatants were used for the assay of enzyme activities by using colorimetric methods as described in materials and methods section. $\mathrm{C}-$ control sample; W - wilted tissues; D - death tissues. Data are the means of three replicates \pm SD

all concentrations of MBP used, a similar localized cell death appears after treatments (Fig. 3).

DNA fragmentation. To test DNA integrity/ fragmentation during the lesion formation, the total genomic DNA was isolated from the MBP-treated areas as well as buffer treated areas as described in materials and methods section. The integrity of the DNA samples was then analyzed on $2 \%$ agarose gel. The result showed that DNA sample from MBP- treated leaves is fragmented to about $200 \mathrm{bp}$ ladder patterns (Fig. 4; ladder DNA marker not presented). Our experiments revealed that DNA fragmentation is started at wilting stage of the treated tissues and then it completed after death. The pattern of the DNA fragmentation is remained in the same pattern with the progress in time. This experiment result suggests that the induced cell death process by MBP might be programmed.

Increase in the antioxidant enzymes activities. For the enzyme activity test, the MBP-treated areas of test plant leaves were cut after wilting and death induction and proceeded for the assessments. It was observed that the activities of catalase, peroxidase and PAL are increased immediately after treatment (Fig. 5). As it has been shown, the activity of catalase is about 1.2 units in control sample, while it reaches to 1.7 units in MBP-treated leaves after $10 \mathrm{~min}$ and it increases to about 2.8 units after $20 \mathrm{~min}$ and then it remains constant.

The activity of peroxidase enzyme was found to be about 0.3 in control sample, while it reaches to 0.9 units after $10 \mathrm{~min}$ and then increases to 1.1 and 1.6 units after 15 and $20 \mathrm{~min}$, respectively. The peroxidase activity remains constant after $20 \mathrm{~min}$ in all treated areas (Fig. 5).

PAL activity is also increased during cell death induction. The results showed that it increases from 1.2 to 8.2 units in control and treated leaves after $10 \mathrm{~min}$, respectively and then it reaches to 12.3 units after $20 \mathrm{~min}$ (Fig. 5). The PAL activity remains constant after $20 \mathrm{~min}$. The increase in the activities of the antioxidative enzymes (catalase and peroxidase) and also in the activity of an enzyme (PAL) involved in the biosynthetic pathway of the antioxidant compounds furthermore reveals that the MBP-induced cell death might be programmed.

Discussion. The present work reports the morphomolecular effects of applying a solution of purified $E$. coli maltose-binding protein to the exterior of $N$. glutinosa leaves, in which it induces symptoms like those of hypersensitive response «a well known example of programmed cell death in plants». $E$. coli is not a plant pathogen or symbiont, but it is a gut microorganism in mammals and birds, with a limited viability outside this environment, and it is not a bacterium to which $N$. glutinosa leaves are likely to be exposed. However, MBP as a transmembrane compound of $E$. coli could able to affect test plant leaf tissues upon exogenous application

ISSN 0564-3783. Цитология и генетика. 2014. T. 48. № 2 
at concentrated amount. This shows that purified MBP may act as an elicitor of a death response in plant system.

Programmed cell death (PCD) constitutes the main form of cell death in plants during developmental processes and in response to different environmental stresses [9]. It is controlled by active morphological and biochemical events. Almost, all of the stimuli and molecular signals that activate programmed cell death are similar in all organisms. On the molecular level, activation of certain transcriptional factors [30], induction of enzymes involved in protein metabolism [31, 32], DNA degradation [11], lipids metabolism [17], phytohormone synthesis [7, 8], ROS production [33] and ion homeostasis alterations $[13,14]$ have been characterized, so far.

Fragmentation of the nuclear DNA appears to be a hallmark of programmed cell death, and the responsible endonucleases may be activated indirectly by proteases that act as PCD regulators $[10,34]$. Recent report revealed a dose-dependent specific nucleosomal DNA fragmentation under ultraviolet B irradiation in tobacco cells [25]. Our DNA fragmentation test reveals that MBP signals PCD and it may be located upstream of proteases need for nuclease activation.

The involvement of ROS in the activation of PCD is well known in plants [35]. The generation of an 'oxidative burst' during the early and late phases of PCD has been well documented, and its role in cell-death signaling has been known very well [33]. In contrast, plants develop several mechanisms that detoxify ROS during PCD process through the development of complex antioxidative system. It has been supposed that the regulation of the expression patterns of antioxidative enzymes such as catalase and peroxidases in sub-cellular level by plants regulates PCD induction. Plants also activate phenylpropanoid pathway and biosynthesis of antioxidant compounds during PCD induction [36]. However, a new report shown that dihydrosphingosine induces programmed cell death in tobacco cells independent of ROS [26].

The increase in the activities of catalase, peroxidase and phenylalanine ammonia lyase in the MBP-treated leaves of $N$. glutinosa in our experiment indicates that cell death induced by MBP is programmed and MBP is considered as signaling molecule of PCD that may be located upstream of ROS.
The results showed that below the $50 \mu \mathrm{g} \mathrm{ml}^{-1} \mathrm{~cm}^{-2}$ of purified MBP no wilting and death symptoms are appeared, while at higher concentrations, the symptoms are not distinguishable in different treatments. This can be explained so that there may be a threshold amount of MBP for the signaling of PCD. If MBP signals PCD through a cascade, so what is important for a morphological response is the signaling.

All these results together indicated that MBP may be an earliest signaling molecule of programmed cell death in test plant leaves, even located upstream of ROS. However, it is not clear whether MBP enters test plant cells without using any tissue abrading material and act as an endogenous inducer, or it induces PCD by exogenous application. Therefore, further investigations are needed to clarify the possible entrance of MBP into plant cells as well as to identify how MBP switches PCD?

Despite these, it needs to be warranted whether the same effects may result from the applying of any other proteins (E. coil or otherwise) to the leaves of this test plant? That is, are the observed symptoms are the generalized response to any non-Nicotiana protein applied to the leaf surface, or they are specific responses to MBP?

The author of this paper is thankful to Research Institute for Fundamental Sciences (RIFS), University of Tabriz for the granting of this work.

\section{A. Gholizadeh}

\section{БЕЛОК, СВЯЗЫВАЮЩИЙ МАЛЬТОЗУ, ВКЛЮЧАЕТ ПРОГРАММИРОВАННУЮ КЛЕТОЧНУЮ ГИБЕЛЬ В КЛЕТКАХ ЛИСТЬЕВ NICOTIANA GLUTINOSA}

Белок, связывающий мальтозу (МСБ), является частью сложной системы регуляции и транспорта мальтозы у Escherichia coli. Он отвечает за поглощение и эффективный катаболизм мальтозы с помощью трансмембранной передачи сигнала за счет АТФ. В настоящей работе показано, что этот бактериальный перипластный белок является индуктором клеточной гибели у Nicotiana glutinosa. При экзогенном нанесении в концентрациях более чем 50 мг/мг очищенный МСБ индуцирует увядание и локализованную клеточную гибель в листьях тестовых растений. Анализ фрагментации ДНК и активности антиоксидантных ферментов показал, что индуцированная гибель клеток может быть запрограммированной. Предполагается, что МСБ может вли- 


\section{A. Gholizadeh}

ять на развитие программированной клеточной гибели через сигналинг активных форм кислорода и регуляцию процессов фрагментации ДНК в листьях тестовых растений, однако механизм такого воздействия подлежит дальнейшему исследованию.

\section{REFERENCES}

1. Mittler A., Lam E. Sacrifice in the face of foes : Pathogen-induced programmed cell death in plants // Trends Microbiol. - 1996. - 4. - P. 10-15.

2. Unsal N.P., Buyuktuncer E.D., Tufekci M.A. Programmed cell death in plants // J. Cell Mol. Biol. - 2005. 4. - P. 9-23.

3. Feys B.J., Parker J.E. Interplay of signaling pathway in plant disease resistance // Trends Genet. - 2000.16. - P. 449-455.

4. Collazo C., Chacyn O., Borrás O. Programmed cell death in plants resembles apoptosis of animals // Biotech. Aplicada. - 2006. - 23. - P. 1-10.

5. Jones D.A. Resistance genes and resistance protein functions // Molecular plant pathology / Eds M. Dickinson, J. Beynon. - Sheffield, 2000. - P. 108143.

6. Daniel X., Lacomme C., Morel J.B., Roby D. A novel $m y b$ oncogene homologue in Arabidopsis thaliana related to hypersensitive cell death // Plant J. 1996. - 20. - P. 591-600.

7. Chandok M.R., Ytterberg J.A., Van Wijk K.J., Klessig D.F. The pathogen-inducible nitric oxide synthase (iNOS) in plants is a variant of the $P$ protein of the glycine decarboxylase complex // Cell. - 2003. 113. - P. 469-482.

8. Leon J., Lawton M.A., Raskin I. Hydrogen peroxide stimulates salicylic acid biosynthesis in Tobacco // Plant Physiol. - 1995. - 108. - P. 1673-1678.

9. Gadjev I., Stone J.M., Gechev T.S. Programmed cell death in plants: new insights into redox regulation and the role of hydrogen peroxide // Int. Rev. Cell and Mol. Biol. - 2008. - 270. - P. 87-144.

10. Mittler R., Lam E. Identification, characterization and purification of a tobacco endonuclease activity induced upon hypersensitive response cell death // Plant Cell. - 1995. - 7. - P. 1951-1962.

11. Balk J., Chew S.K., Leaver C.J., McCabe P.F. The intermembrane space of plant mitochondria contains a DNAse activity that may be involved in programmed cell death // Plant J. - 2003. - 34. - P. 573-583.

12. Solomon M., Belengi B., Delledonne M. et al. The involvement of cysteine proteinases and protease inhibitor genes in the regulation of programmed cell death in plants // Plant Cell. - 1999. - 11. P. 431-443.

13. Clough S.J., Fengler K.A., Yu I-C. et al. The Arabidopsis dnd1 'defense, no death' gene encodes a mutated cyclic nucleotide-gated ion channel // Proc.
Nat. Acad. Sci. USA. - 2000. - 97. - P. 93239328.

14. Balague C., Lin B., Alcon C. et al. HLM1, an essential signaling component in the hypersensitive response, is a member of the nucleotide-gated channel ion channel family // Plant Cell. - 2003. - 12. P. 365-379.

15. Brodersen P., Petersen M., Pike H.M. et al. Knockout of Arabidopsis ACCELERATED-CELL-DEATH11 encoding a sphingosine transfer protein causes activation of programmed cell death and defense // Genes Dev. - 2002. - 16. - P. 490-502.

16. Nandi A., Krothapalli K., Buseman C.M. et al. Arabidopsis sfd mutants affect plastidic lipid composition and suppress dwarfing, cell death, and the enhanced disease resistance phenotypes resulting from the deficiency of a fatty acid desaturase // Plant Cell. 2003. - 15. - P. 2383-2398.

17. Jirage D., Tootle T.L., Reuber T.L. et al. Arabidopsis thaliana PAD4 encodes a lipase-like gene that is important for salicylic acid signaling // Proc. Nat. Acad. Sci. USA. - 1999. - 96. - P. 13583-13588.

18. Davinson A.L., Shuman H.A., Nikaido H. Mechanism of maltose transport in Escherichia coli : Transmembrane signaling by periplasmic binding proteins (ATPase/uncoupling) // Proc. Nat. Acad. Sci. USA. - 1992. - 89. - P. 2360-2364.

19. Daus M.L., Berendt S., Wuttge S., Schneider E. Maltose binding protein (MalE) interacts with periplasmic loops P2 and P1 respectively of the MalFG subunits of the maltose ATP binding cassette transporter (MalFGK(2)) from Escherichia coli/Salmonella during the transport cycle // Mol. Microbiol. - 2007. 66. - P. 1107-1122.

20. Richarme G., Caldas T.D. Chaperone properties of the bacterial periplasmic substrate-binding proteins // J. Biol. Chem. - 1997. - 272. - P. 607-612.

21. Kapust R.B., Waugh D.S. Escherichia coli maltosebinding protein is uncommonly effective at promoting the solubility of polypeptides to which it is fused // Protein Sci. - 1999. - 8. - P. 1668-1674.

22. Fox J.D., Kapust R.B., Waugh D.S. Single amino acid substitutions on the surface of Escherichia coli maltose-binding protein can have a profound impact on the solubility of fusion proteins // Protein Sci. 2001. - 10. - P. 622-630.

23. Gholizadeh A. Heterologous expression of stress-responsive DUF538 domain contaning protein and its morpho-biochemical consequences // Protein J. 2011. - 30. - P. 351-358.

24. Gholizadeh A. Molecular analysis of maize cystatin expression as fusion product in Escherichia coli // Physiol. Mol. Biol. Plants. - 2012. - 18. - P. 237244.

25. Lytvyn D.I., Yemets A.I., Blume Y.B. UV-B over- 
exposure induces programmed cell death in a BY-2 Tobacco cell line // Environ. Exp. Bot. - 2011. 68. - P. 51-57.

26. Lachauda C., Da Silvaa D., Amelota N. et al. Dihydrosphingosine-induced programmed cell death in Tobacco BY-2 cells is independent of $\mathrm{H}_{2} \mathrm{O}_{2}$ production // Mol. Plant. - 2011. - 4. - P. 310318.

27. Laemmli U.K. Cleavage of structural proteins during the assembly of the head of bacteriophage T4 // Nature. - 1970. - 227. - P. 680-685.

28. Luck $H$. Estimation of catalase // Methods in enzymatic analysis / Ed. L.H. Bergmeyer. - New York : Acad. press, 1974. -885 p.

29. Bergmeyer H.U. Methods of enzymatic analysis. New York : Acad. press, 1974. - 495 p.

30. Wilson I., Volgel J., Somerville S. Signaling pathways a common theme in plants and animals? // Curr. Biol. - 1997. - 7. - P. 175-178.

31. Dsilva I., Poirier G.G., Heath M.C. Activation of cysteine proteinases in cowpea plants during the hypersensitive-response - a form of programmed cell death // Exp. Cell Res. - 1998. - 245. - P. 389399.
32. Uren A.G., O'Rourke K., Aravind L.A. et al. Identification of paracaspases and metacaspases: two ancient families of caspase-like proteins, one of which plays a key role in MALT lymphoma // Mol. Cell. - 2000. - 6. - P. 961-967.

33. Yoda H., Yamaguchi Y., Sano H. Induction of hypersensitive cell death by hydrogen peroxide produced through polyamine degradation in tobacco plants // Plant Physiol. - 2003. - 132. - P. 1973-1981.

34. Nicholson D.W., Ali A., Thornberry N.A. et al. Identification and inhibition of the ICE/CED-3 protease necessary for mammalian apoptosis // Nature. 1995. - 376. - P. 37-43.

35. Pennell R.I., Lamb C. Programmed cell death in plants // Plant Cell. - 1997. - 9. - P. 1157-1168.

36. Legrand M., Fritig B., Hirth L. Enzymes of the phenylpropanoid pathway and the necrotic reaction of hypersensitive tobacco to tobacco mosaic virus // Phytochemistry. - 1976. - 15. - P. 1353-1359. 